\title{
Textual Strategies to Resist Disappearance and the Mothers of Plaza de Mayo
}

\author{
Alicia Partnoy \\ Loyola Marymount University
}

Follow this and additional works at: https://docs.lib.purdue.edu/clcweb

Part of the Comparative Literature Commons, and the Critical and Cultural Studies Commons

Dedicated to the dissemination of scholarly and professional information, Purdue University Press selects, develops, and distributes quality resources in several key subject areas for which its parent university is famous, including business, technology, health, veterinary medicine, and other selected disciplines in the humanities and sciences.

CLCWeb: Comparative Literature and Culture, the peer-reviewed, full-text, and open-access learned journal in the humanities and social sciences, publishes new scholarship following tenets of the discipline of comparative literature and the field of cultural studies designated as "comparative cultural studies." Publications in the journal are indexed in the Annual Bibliography of English Language and Literature (Chadwyck-Healey), the Arts and Humanities Citation Index (Thomson Reuters ISI), the Humanities Index (Wilson), Humanities International Complete (EBSCO), the International Bibliography of the Modern Language Association of America, and Scopus (Elsevier). The journal is affiliated with the Purdue University Press monograph series of Books in Comparative Cultural Studies. Contact: <clcweb@purdue.edu>

\section{Recommended Citation}

Partnoy, Alicia. "Textual Strategies to Resist Disappearance and the Mothers of Plaza de Mayo." CLCWeb: Comparative Literature and Culture 9.1 (2007): <https://doi.org/10.7771/1481-4374.1028>

This text has been double-blind peer reviewed by $2+1$ experts in the field.

The above text, published by Purdue University Press @Purdue University, has been downloaded 4895 times as of $11 /$ $07 / 19$.

This document has been made available through Purdue e-Pubs, a service of the Purdue University Libraries. Please contact epubs@purdue.edu for additional information.

This is an Open Access journal. This means that it uses a funding model that does not charge readers or their institutions for access. Readers may freely read, download, copy, distribute, print, search, or link to the full texts of articles. This journal is covered under the CC BY-NC-ND license. 


\title{
CLCWeb: Comparative Literature and Culture
}

ISSN 1481-4374 <http://docs.lib.purdue.edu/clcweb> Purdue University Press (C)Purdue University

CLCWeb: Comparative Literature and Culture, the peer-reviewed, full-text, and open-access learned journal in the humanities and social sciences, publishes new scholarship following tenets of the discipline of comparative literature and the field of cultural studies designated as "comparative cultural studies." In addition to the publication of articles, the journal publishes review articles of scholarly books and publishes research material in its Library Series. Publications in the journal are indexed in the Annual Bibliography of English Language and Literature (Chadwyck-Healey), the Arts and Humanities Citation Index (Thomson Reuters ISI), the Humanities Index (Wilson), Humanities International Complete (EBSCO), the International Bibliography of the Modern Language Association of America, and Scopus (Elsevier). The journal is affiliated with the Purdue University Press monograph series of Books in Comparative Cultural Studies. Contact: <clcweb@purdue.edu>

\section{Volume 9 Issue 1 (March 2007) Article 16 Alicia Partnoy, \\ "Textual Strategies to Resist Disappearance and the Mothers of Plaza de Mayo" <http://docs.lib.purdue.edu/clcweb/vol9/iss1/16>}

\author{
Contents of CLCWeb: Comparative Literature and Culture 9.1 (2007) \\ Thematic Issue Representing Humanity in an Age of Terror \\ Edited by Sophia A. McClennen and Henry James Morello \\ <http://docs.lib.purdue.edu/clcweb/vol9/iss1/>
}

\begin{abstract}
In her paper "Textual Strategies to Resist Disappearance and the Mothers of Plaza de Mayo" Alicia Partnoy draws attention to the ways the Mothers of the Plaza de Mayo use literature as both a form of protest and as a way to build solidarity. Focusing on four texts written by the Mothers, Partnoy attempts to correct the lack of attention that this literary work has drawn. Partnoy suggests that in addition to the forms of public protest engaged by the Mothers, their literary activities also play a central role in their efforts. In fact, their use of the literary form cannot be separated from their political activities. It is only through careful analysis of their writing, Partnoy suggests, that we can begin to understand the Mothers as subjects and not as objects of analysis. Moreover, it is through their writing that the women have been able to achieve much success in their struggle. Their texts serve as a form of testimonial memory and also as a form of political activism.
\end{abstract}


Alicia Partnoy, "Textual Strategies to Resist Disappearance and the Mothers of Plaza de Mayo" page 2 of 9 CLCWeb: Comparative Literature and Culture 9.1 (2007): <http://docs.lib.purdue.edu/clcweb/vol9/iss1/16> Thematic Issue, Representing Humanity in an Age of Terror. Ed. Sophia A. McClennen and Henry James Morello

\section{Alicia PARTNOY}

\section{Textual Strategies to Resist Disappearance and the Mothers of Plaza de Mayo}

More than thirty years ago, on 30 April 1977 Azucena Villaflor de De Vincenti led a dozen of women to the Plaza de Mayo in Argentina's capital city. Coming from a range of backgrounds the women had one thing in common: they all had children who had been disappeared by the military government. By choosing to demonstrate across the street from the presidential office building, la Casa Rosada (the Pink House), the mothers were seeking public visibility as a strategy to rescue their children, who had been kidnapped and kept in secret detention places. In addition to marching, the mothers also launched an international campaign to counter the propaganda issued by the regime and their efforts drew the attention of the world. When the mothers first marched, I too, was a disappeared. Through their courage to risk their own lives, the mothers became instrumental to securing my survival . Their efforts also led to the eventual ousting of the military regime and the reinstating of democracy. Despite these successes, most of the mothers' children never returned alive.

Although much attention has been paid to the Mothers of the Plaza de Mayo, Villaflor de De Vincenti's leadership role in the mothers' movement and its consequences remain largely ignored by the international community. In December of 1977, she was kidnapped. After enduring torture in Argentina's largest secret detention camp, the Navy Mechanics School (ESMA), Azucena was thrown from a plane into the Atlantic Ocean. Her body reached the shores of a little town south of Buenos Aires and remained buried as an NN (no name) for several decades. In 2005, forensic anthropologists finalized a lengthy investigation dedicated to confirming her identity. Then in December of that year her ashes were scattered in the Plaza de Mayo and a plaque with her name was left there by thousands of demonstrators. According to the words of her daughter Cecilia, "Here my mother was born to public life, and here she must remain forever" (Keve <http://www.pagina12.com.ar/diario/elpais/160225-2005-12-09.html>; my translation). On the plaque a bronze water lily, or azucena in Spanish, represents courageous Azucena. The same emblem and Villaflor de De Vincenti's photo figure prominently in the three volumes of Cantos de vida, amor y libertad (Songs of Life, Love, and Liberty), the poetry anthologies penned by the mothers during the dictatorship.

Much has been written about the organizations created by the mothers of the disappeared, the women's weekly demonstrations in the plaza, their specific strategies to search for the children born in captivity, their international campaigns for justice, and the semiotic value of the pictures displayed in their events. Very little attention, however, has been paid to these women as published authors. In the United States, scholars Diana Taylor, Margarite Bouvard, Jo Fisher, Rita Arditti, and Marjorie Agosín, to name a few pioneers in the field, have discussed the diverse strategies used by the mothers to reestablish the presence of their children through what, borrowing from social semiotics theories developed by Robert Hodge and Gunther Kress, I have identified as the construction of a "discourse of solidarity" (see El discurso de la solidaridad). My contribution to the analysis of testimonial texts suggests that it is necessary to go beyond the truth value or the literary characteristics of the texts. In particular, I suggest that the process of their production and dissemination helps explain how they are positioned within discourses of solidarity that emphasize community over individuality. Jean Franco's article "Beyond Ethnocentrism: Gender, Power, and the Third-World Intelligentsia," provides one of the finest social semiotic analyses of the Mothers of the Plaza de Mayo's intervention in the political life of the country:

These women have not only redefined public space by taking over the center of Buenos Aires on one afternoon every week but they have also interrupted military discourse . . . publicly displaying the photographs of sons and daughters who have "disappeared." This form of refusing a message of death is obviously quite different from the 
Alicia Partnoy, "Textual Strategies to Resist Disappearance and the Mothers of Plaza de Mayo" page 3 of 9 CLCWeb: Comparative Literature and Culture 9.1 (2007): <http://docs.lib.purdue.edu/clcweb/vol9/iss1/16> Thematic Issue, Representing Humanity in an Age of Terror. Ed. Sophia A. McClennen and Henry James Morello

quest for immortality that has traditionally inspired the writer and the political leader. The women interrupted the military by wrestling meaning away from them and altering the connotations of the word "mother." To the military, they were the mothers of dead subversives, therefore, of monsters. But they have transformed themselves into the "mothers of Plaza de Mayo," that is, in the words of one of them, into "mothers of all the disappeared," not merely their own children. They have thus torn the term "mother" from its literal meaning as the biological reproducer of children and insisted on social connotations that emphasize community over individuality. (514).

These characteristics still apply to the two main organizations where the women join in action: the Mothers of Plaza de Mayo -- the group that runs the Casa de las Madres and the Universidad de las Madres, under the leadership of Hebe de Bonafini, and the Mothers Línea Fundadora (The Founding Group) where Laura Bonaparte and Matilde Mellibovsky have important leadership roles. The groups embrace different, often conflicting, approaches to action in pursuit of their goals. Both have, however, contributed to building a strong cultural movement by organizing music and film festivals, publishing enterprises, poetry and public monument contests, art shows, and theater performances. Given that these forms of protest have been deeply connected to using culture as a form of public intervention, it is paradoxical that their own writings remain neglected.

Despite the strong impulse to validate the victims' and survivors' words and experiences that permeates Argentina's society today, cultural critics in the country and abroad have yet to discover most of the mothers' writings, including the four books discussed in this article. These narrative texts provide multiple clues to understand the resistance strategies of the mothers of the disappeared. Originally published in the early nineties, three of these books had very little distribution in Argentina. A fourth text, El corazón en la escritura (The Heart in Our Writing), published in 1997, is sold at the table set in the Plaza every Thursday by the Mothers of Plaza de Mayo, the first of the groups mentioned above. The Mothers of the Plaza de Mayo and the Mothers Línea Fundadora have produced a series of texts that share a common project: the transformation of absence into presence through the written word. The books are as diverse as their authors. El corazón en la escritura, is a polyphonic testimony, the product of writing workshops offered at the Casa de las Madres in Buenos Aires. El mundo guarda silencio: La tragedia de Cañuelas (The World Keeps Silent: Tragedy in Cañuelas) is a novel written by Laura Bonaparte, a political activist and the mother of three disappeared children who is affiliated with the Mothers Línea Fundadora. Hasta la victoria siempre ... Testimonio de Carmen Cornes, emigrante gallega y militante de la vida (Till Victory, Forever ... Testimonio by Carmen Cornes, Galician Emigrant, Militant in Life) is a testimonial by a mother who learnt about the disappearance of her son while she was a political prisoner in Buenos Aires. The book resembles the paradigmatic testimonial text I, Rigoberta Menchú: An Indian Woman from Guatemala. Performing a similar role as did Elizabeth Burgos-Debray, journalist and activist Beatriz López transcribed hours of interviews with Carmen Cornes (Carmiña) and she secured publication of the work in Galicia, Spain. The fourth book, Mellibovsky's outstanding history of the mothers' movement, is the only one available in English. In Circle of Love over Death (Círculo de amor sobre la muerte) the author weaves testimonies by several mothers with accounts and reflections about her personal ordeal. The book blends the personal with the national teaching readers about the history of Argentina and also the history of her movement.

The texts unravel the demonization of victims and activists that operated as the main rationale for the dictatorship's campaign to exterminate "subversives." The writing of the Mothers highlights the presence and the humanity of the disappeared thereby challenging the regime's efforts to erase them from society, from collective memory, and from official history. The texts by the mothers/authors accomplish this goal by building a discourse of solidarity around their disappeared children, and by dismantling the dictatorship's messianic discourse of power. It is noteworthy that after years of enjoying a rather small readership, two recent publishing developments signal a renewed interest in their writing. There is now a new edition of Mellibovsky's book and Carmen Cornes published her testimony, at 
Alicia Partnoy, "Textual Strategies to Resist Disappearance and the Mothers of Plaza de Mayo" page 4 of 9 CLCWeb: Comparative Literature and Culture 9.1 (2007): <http://docs.lib.purdue.edu/clcweb/vol9/iss1/16> Thematic Issue, Representing Humanity in an Age of Terror. Ed. Sophia A. McClennen and Henry James Morello

the initiative of her grandson, Nicolás, in Argentina

$<$ http://www.madresfundadoras.org.ar/cultura.shtml>.

These recent publications reveal that the construction of a discourse of solidarity is still operating within the writings of the Mothers. For instance, the new generation, as presented by Carmen Cornes's grandson, is part of a semiotic structure that, following Hodge and Kress, "incorporates the text with its discursive processes" (267). Hodge and Kress, authors of Social Semiotics, demand that the scholar engaging in textual analysis clearly disclose her role within that structure. As a survivor, a teacher, and a public intellectual, I have actively participated in the construction of a discourse of solidarity around these books, interacting with the authors and their texts in multiple occasions, and this article is merely one example of these ongoing efforts. Hodge and Kress understand discourse as the "social process in which texts are embedded" and as the "site where social forms of organization engage with systems of signs in the production of texts, thus reproducing or changing the sets of meanings and values which make up a culture" (6). To build a discourse of solidarity, participants must privilege the development of paratactic (non hierarchical) relationships. But the Mothers are rarely read in this way. Patronizing the mothers as authors by editors and established writers or relegating the disappeared to the category of non-persons undermines a discourse of solidarity that seeks to empower both victims and survivors. I propose to read the work of the Mothers non-hierarchically.

To continue with the premises outlined by Hodge and Kress that have helped shape my critical perspective, social semiotic analysis demands that we define the mimetic anchorage, the "world of referents ... independently of the mimetic content of the text" (267). To that end, let us look at two decrees issued in Argentina in September 1979 that sought to eliminate the disappeared as individuals before the law (juris personae). The Presumption of Death after a Disappearance Law (Ley de Fallecimiento Presunto por Desaparición) stated that "the presumption of death by disappearance can be ruled in the cases of persons whose disappearance from their home or residence, without further information on their whereabouts, has been denounced convincingly between 6 November 1974, date when the State of Siege was declared, and the date the present decree was promulgated" (CIDH 13739; my translation). This decree was in tandem with the Law for Welfare Benefits in Case of the Absence of Persons, which under the pretext of helping the relatives of the disappeared file paperwork for inheritance, property sales, pensions and other benefits, insisted that the relatives stated their acceptance of the civic death of their loved ones.

It is within this context that we must read certain features in the mothers' writings, for example those that mimic legal documentation and official ID cards, documents commonly associated with the juris personae of the disappeared ones that the regime wanted to exile from public memory and civic protection. In Desde el silencio: Escritos de jóvenes secuestrados-desaparecidos durante la dictadura (From Silence: Writings by the Disappeared-Kidnapped Youth During the Dictatorship), a poetry anthology by college and high school age victims, each poem is preceded by a page stating the name, birth date, and date of disappearance of the author, and a picture, in most cases copied from their government issued ID card. Círculo de amor sobre la muerte (Circle of Love Over Death) displays a similar strategy by documenting the legal existence of the disappeared person: every testimonio starts with the name of the mother who presents it, and the words "mother of ... kidnapped at age ... on (date)." Furthermore, the pages that reproduce these testimonies are framed by a thin line that reminds us of the stationary used for legal depositions.

Collected through personal interviews with the other mothers in the movement, the testimonies in Mellibovsky's book, in keeping with the social urgency of testimonial texts, seek to move readers to actively attempt to stop the crimes. The modus operandi of these texts, according to George Yúdice, is the "communicative construction of a praxis of solidarity and emancipation" ("construcción 
Alicia Partnoy, "Textual Strategies to Resist Disappearance and the Mothers of Plaza de Mayo" page 5 of 9 CLCWeb: Comparative Literature and Culture 9.1 (2007): <http://docs.lib.purdue.edu/clcweb/vol9/iss1/16> Thematic Issue, Representing Humanity in an Age of Terror. Ed. Sophia A. McClennen and Henry James Morello

comunicativa de una praxis solidaria y emancipatoria") (216; also qtd. in Bartow 46). Amy Kaminsky's observations in Reading the Body Politic move in the same direction when she states that a support network of mostly feminist women has secured the dissemination of my own testimonial texts in the U.S (49). She discusses the relationships that link the diverse participants in the text production process (illustrators, preface writers, publishers), and their interaction with literary critics and other readers. These relationships build a discourse of solidarity, one that creates a community of allies who support resistance to political repression.

According to René Jara, testimonial texts "go beyond [offering] an interpretation of reality ... [they] are traces of the real, of that story that cannot be expressed as such. The image inscribed in the testimonio is the material vestige of the victimized subject" (2; my translation). When their children have been made to disappear, and the authorities simultaneously deny their existence, and describe them as undeserving to remain among the living, the mothers engage in the production of those material traces in their own writings. These texts create a material presence in the face of absence. The words of the Mothers seek to overcome the silence of their loved ones. To create material traces of the lives and deeds of their children was not a difficult task for the Mothers. In contrast, publishing their works and generating presence outside the space of the Plaza de Mayo was a real challenge. In the late 1980s, after democracy was consolidated in Argentina, Mellibovsky began searching for a publisher for Círculo de amor sobre la muerte (Circle of Love over Death). In the first chapter of the book, a testimonio finalist in the prestigious Casa de las Américas contest, Mellibovsky writes, "I take the manuscript to an editor. He rejects it, saying piously, 'all the Mothers say the same thing. They nostalgically exalt their children because they are no longer here'" (1). The publisher's words echo the official propaganda in its portrayal of the disappeared as totally undeserving of 'exaltation' even by their own mothers. It was also implied that because the Mothers shared a discursive solidarity of love and loss, they had nothing new to say of interest to the reading public.

To resist their children's erasure from the historic memory of their country, the women persisted in representing and idealizing them. Mellibovsky's process when collecting the stories of other mothers for her book reveals the collective strength of that resistance, "When I ask the Mothers to leave testimonies of all these events -- history in the making -- they all say, 'Let's stop talking about the Mothers, because enough has already been said about them. We have to talk about the children themselves'" (2). It is against the assertion that "they are no longer here," uttered in this case by the publisher, but echoed by many sectors of the Argentine society, that the mothers insisted in writing poem after poem, testimonio after testimonio, with their children featured as a concrete and permanent presence whose dreams and struggles for social change were revisited and embraced. The concept of discourse as a social process linked to mechanisms and institutions that "mediate and control the flow of knowledge and power in a community" (Hodge viii) helps us understand the dynamics of the mothers/authors as they confront hegemonic powers through their texts. In the beginning pages of Circle of Love over Death, Mellibovsky states: "I keep on thinking that all the talk about the Mothers is continually being used ... by journalists. In contrast, when it's us who tell about our own experiences, the first thing we describe is our children: how they were, what they dreamt about, what they were fighting for" (2). Equally telling is Laura Bonaparte's reply when I asked her during an interview to identify the force that drove her to write El mundo guarda silencio. La Tragedia de Cañuelas (The World Keeps Silent: The Tragedy of Cañuelas): "I wanted to resurrect that baby by all possible means. It was as if I refused to believe in the level of cruelty displayed by the military as an institution" (Personal Interview 1999). Both Carmen Cornes and Porota, one of the authors of El corazón en la escritura (The Heart in the Writing) refer frequently to the relationship with their disappeared children as sources of creativity and positive transformation in their lives. In Hasta la victoria siempre ... 
Alicia Partnoy, "Textual Strategies to Resist Disappearance and the Mothers of Plaza de Mayo" page 6 of 9 CLCWeb: Comparative Literature and Culture 9.1 (2007): <http://docs.lib.purdue.edu/clcweb/vol9/iss1/16> Thematic Issue, Representing Humanity in an Age of Terror. Ed. Sophia A. McClennen and Henry James Morello

Testimonio de Carmen Cornes (Till Victory Forever ... Testimonial by Carmen Cornes), compiled by Beatriz López, Cornes tells López, "My son made me grow this way. Sometimes I think he should be the one living through all this. But Miguel Angel had to die so that I could be alive" (141). Similarly, Porota remarks regarding the collage-like texts produced by the mothers: "This makes me think ... in something that our children used to tell us all: that we had to take more care of ourselves, and at the same time to learn how to share in a communal way (socializar). And this makes me think about what for us is the most important aspect of our growth: the socialización of our motherhood" (124). The socialización (socialization) of motherhood, a key component of the Mothers de Plaza de Mayo, is the practice of motherhood as a communal experience, in which mothers share their disappeared children, instead of seeing them as "private property."

All these quotes provide clues to several textual strategies that reestablish the presence of the disappeared. While Mellibovsky proposes to re-deploy the readers' attention from herself and the other mothers to their children, Carmen Cornes presents her own life as a construction and product of her absent son. To the socialización of motherhood proposed by Porota as a kind of ideological legacy of her son, we must add Laura Bonaparte's textual resurrection of a disappeared baby. Bonaparte's approach is revolutionary, since she re-appropriates and rewrites texts sacred to the Catholic Church, the institution that acted in Argentina as an accomplice to her own daughter's disappearance. Bonaparte's messianic message of hope appears in stark contrast with her succinct account at the end of her book summarizing the kidnapping of her three children, their husbands and wives, and the author's former husband -- the father of her children (141-43). Another textual device employed by Bonaparte to leave material traces of her disappeared family members, is the book cover featuring "a drawing sent by Irene Monica Bruschtein de Ginzberg (age 22) to her mother, Laura Bonaparte, before her kidnapping along with her husband Mario Ginzberg (age 24) by the Armed Forces, with total knowledge of the high hierarchy of the Church" (4). This image makes of her daughter and active participant in the elaboration of this book, a cultural artifact generated after her disappearance, and therefore a reminder of Graciela's presence in absence. In a move that sets her apart from most of the mothers, Bonaparte openly states her personal history of political activism and awareness, previous to the victimization of her entire family. She also strongly disagrees with the idea that motherhood must be socializada or seen as a communal practice. "We insist in clearly establishing the identity of all the disappeared," Bonaparte, a psychologist and university professor, stated in a personal interview that took place in Argentina in June 1999. And she added, "When her children are taken away from a mother, she is no longer a mother, there is no mother who can be so with a disappeared or dead child since, with whom can she exercise her motherhood?"

In the same interview, Laura Bonaparte recalled an incident that shocked her deeply and propelled her to write her novel. She had been summoned by the police to identify, years after his assassination, the body of her former husband Santiago Bruschtein. In the process, pictures of the event that had caused his death were displayed in front of her, "but you know, [in my novel] I make the baby come back to life ... Six persons were burnt, among them Santiago, and the firefighters were stressed out ... The firefighters literally stated that because of the heat the mother's internal tissues softened and her body fluids heated and there was an explosion, an explosion! To use that word, a strong sound must have been produced ... besides, I have the picture of the little baby and he looks like a small angel, his tiny arms like this, like little wings, and he dragged the mother's placenta with his umbilical cord ... and that is in a picture! I went crazy when I saw that photo. I wanted to resurrect that child" (Personal Interview 1999). In her novel, a baby is found in similar circumstances, and receives the name of Jesús. He is rescued and raised by Celeste, a peasant from the northeastern province of Entre Rios, and his wife, María, a former prostitute. His adoptive parents never tell young Jesús 
Alicia Partnoy, "Textual Strategies to Resist Disappearance and the Mothers of Plaza de Mayo" page 7 of 9 CLCWeb: Comparative Literature and Culture 9.1 (2007): <http://docs.lib.purdue.edu/clcweb/vol9/iss1/16> Thematic Issue, Representing Humanity in an Age of Terror. Ed. Sophia A. McClennen and Henry James Morello

about his past, but when he grows up, and returns as a rock singer to the town of Cañuelas, his birth site, he starts his concert with a prophetic song, "I don't know who I am / I was born a No Name amidst a bonfire / I've been here, speaking in silence / I've been here / I've been here / We've been here" (135). Bonaparte's novel recovers memory and rewrites a myth of origin. The disappeared Jesús interprets his own existence as a collective one. After the concert, María goes back to her copy of the Latin American Bible -- an edition that had been labeled "subversive" and banned by the military regime. She highlights a passage that reads, "you rejoiced while others were assassinated. You killed the innocent one, it was easy to condemn him, since he was not able to defend himself" (136). This textual strategy seeks to include in the construction of the discourse of solidarity, the countless young people who were involved in the Liberation Theology movement that was severely targeted by the dictatorship.

When writing The Discourse of Solidarity in Testimonial "poemarios" from Argentina, Chile, and Uruguay, I identified in the poetry anthologies of Cantos de vida y esperanza a strategy used by the mothers to reestablish the presence of the disappeared and to rebuild their public image. They repeatedly appropriated the role of the Virgin Mary for themselves, and the role of Jesus for their children. While the regime portrayed the disappeared as terrorists opposed to the Christian faith, prone to attack their country, guilty of making their parents suffer, and unworthy of raising their own children, their mothers reproduced in their writings elements of liberation theology that not only countered the rulers' demonizing, but reestablished the presence of the victims by actualizing the ideological constructs they had embraced. In addition to the poetry collections published in the early 1980s, the Mothers of the Plaza de Mayo continued sharing their poems. An important group attended a workshop led by writer Leopoldo Brizuela at the Casa de las Madres. Some of the narratives produced there are published in El corazón en la escritura (The Heart in the Writing). This text is similar to Circle of Love over Death, in its polyphonic approach. Both collections feature a multiplicity of voices portraying the disappeared. The testimonios are in a paratactic, non hierarchical relationship that is the main characteristic of the discourse of solidarity. However, the omission of last names for both the mothers and their children in El corazón en la escritura (The Heart in the Writing) illustrates one of the stark differences that would ultimately cause a division in the Mothers movement in 1988. The socialización of motherhood is enacted by erasing all last names, suggesting that one disappeared person does not "belong" to a particular mother but to all. This also mimics dramatically the situation of militancy that lead to most disappearances. In those times, for security reasons, we did not share our last names, we called each other by aliases, in most cases names that could not be associated with ours. When the mothers advocate for the socialización of motherhood, they remind us that large sectors of the population victimized by the genocidal regime advocated socialism, or embarking in a road towards a socialist political model for the country.

Despite the strong differences among the mother's organizations, the only reference to their 1988 division in the four books discussed in this article are a couple of paragraphs in Mellibovsky's Circle of Love over Death, where the author refers to the origin of her group, Línea Fundadora. She writes that they remain "separated from our sisters, but we never confront each other; we all persevere in our firm decision not to give up" (179). Despite their ideological differences, both groups resort to photography as a way to document the history of the disappeared. Línea Fundadora's members tend to carry pictures of their own children, whose names they embroider in their white scarves. Bonaparte displays an impressive number of pictures in buttons pinned to her clothing every Thursday, when she joins the other mothers in their march around the historical pyramid of the Plaza de Mayo. Photography as a transparent sign of identity and as a way to document the history of the disappeared also appears prominently in Hasta la victoria siempre.... (Till Victory, Forever). The testimonial subject, Carmen 
Alicia Partnoy, "Textual Strategies to Resist Disappearance and the Mothers of Plaza de Mayo" page 8 of 9 CLCWeb: Comparative Literature and Culture 9.1 (2007): <http://docs.lib.purdue.edu/clcweb/vol9/iss1/16> Thematic Issue, Representing Humanity in an Age of Terror. Ed. Sophia A. McClennen and Henry James Morello

Cornes, aka Carmiña, shares a history of resistance with her son and she reestablishes his presence within the community of prisoners, when she refers to her spirit of resistance as a value she shares with him. Carmiña's life narrative functions as a way to perpetuate the presence of Miguel Angel. In one of the most dramatic passages, she recalls an experience in the women's prison of Villa Devoto in Buenos Aires. It is her birthday and there is a celebration prepared by the other prisoners. Fate has it that the very same day, news arrives about the kidnapping of her son, Miguel. Carmiña emphasizes militant camaraderie and prison solidarity as values learned from him, "When Miguel was imprisoned for the first time I went to see him and he said: 'No steak for your sweet little child, ok? Anything you bring here is to be shared.' That way he began teaching me about life in jail. So when I went in I knew, that's why I walked in prison with all that willpower" (104). Those notions of prison solidarity made her channel her pain through the collective celebration of her birthday: "One morning, after they open our cells ... I see that the girls look at me, and they look at me and they come rushing towards me and they look at me as if I was a stranger and I immediately said 'Miguel Angel! Miguel Angel is disappeared'... 'Cause they were looking at me with those eyes oh so sad,' 'Yes Carmiña. Miguel Angel has disappeared. We have to be strong.' And that was the day of my birthday. I turned sixty six. I don't know how the girls had found out about Miguel, maybe somebody had told them. I was the last one in finding out. And the girls had not eaten their bread for eight days, they saved it, and chocolate, to celebrate my birthday. And that's why when they came to me that morning after the cells were opened I told them 'We'll have our party anyway and we'll celebrate the birthday' ... It was very hard for me but I had to be strong" (104-05).

The women active in the organizations Mothers of Plaza de Mayo and Mothers of Plaza de MayoLínea Fundadora engaged in strong resistance to the messianic discourse of power that sought to erase the disappeared from history and collective consciousness. Most of the women's activities have been documented and analyzed by scholars in Argentina and abroad, but their writings remain among the most neglected aspects of their work. Perhaps this failure to recognize their contributions as authors is a consequence of the academic construction of knowledge. To see the Mothers as both victims and also as authors, as objects of repression and as narrators of their own lives introduces fissures in the traditional flow of discourse. The difficulty in overcoming these gaps demonstrates one of the most vulnerable aspects of a critical project dedicated to building a discourse of solidarity: the intersection between academic/literary culture and popular culture. Hierarchical relationships tend to be an extremely strong feature of academia and of the world of letters in general. To empower the Mothers we have to make efforts to see them as subjects, and not just objects of our scholarly inquiries: we must listen to their words, and their ideas, read their writings. Maybe then we could venture an answer to Porota's questions in Con el corazón en la escritura (The Heart in the Writing), "Who would have expected that we would get involved in the struggle? Who would have expected that we would write? And now, who would want to read us, now?" (112).

Note: A different version of this article in Spanish has been published in Spanish in Mujeres, literaturas, politicas $y$ compromisos en el Nuevo Milenio: diálogos transatlánticos, Ed. Guadalupe Cortina. Ediciones Nuevo Espacio < http://www.editorial-ene.com>,

2007. 
Alicia Partnoy, "Textual Strategies to Resist Disappearance and the Mothers of Plaza de Mayo" page 9 of 9 CLCWeb: Comparative Literature and Culture 9.1 (2007): <http://docs.lib.purdue.edu/clcweb/vol9/iss1/16> Thematic Issue, Representing Humanity in an Age of Terror. Ed. Sophia A. McClennen and Henry James Morello

\section{Works Cited}

Arditti, Rita. Searching for Life. Berkeley: U of California P, 1999.

Agosín, Marjorie. Circles of Madness: Mothers of the Plaza de Mayo. Fredonia: White Pine P, 1992.

Bartow, Joanna. Subject to change: The Lessons of Latin American Woman's Testimonio for Truth, Fiction, and Theory. Chapel Hill: U of North Carolina P. 2006.

CIDH: Comisión Interamericana de Derechos Humanos. Informe sobre la situación de los derechos humanos en Argentina. Washington: Organización de los Estados Americanos, 1980.

Bouvard, Marguerite Guzmán. Revolutionizing Motherhood: The Mothers of the Plaza de Mayo. Oxford: SR Books, 1994.

Bonaparte, Laura. El mundo guarda silencio. La Tragedia de Cañuelas. Buenos Aires: Catálogos, 1993.

Fisher, Jo. Mothers of the Disappeared. Boston: South End P, 1989.

Franco, Jean. "Beyond Ethnocentrism: Gender, Power, and the Third-World Intelligentsia." Marxism and the Interpretation of Culture. Ed. Cary Nelson and Lawrence Grossberg. Urbana: U of Illinois P, 1988. 503-15.

Hodge, Robert. Literature as Discourse: Textual Strategies in English and History. Baltimore: Johns Hopkins UP, 1990.

Hodge, Robert, and Gunther Kress. Social Semiotics. Ithaca: Cornell UP, 1988.

Jara, René. "Prólogo." Testimonio y literatura. Ed. René Jara and Hernán Vidal. Minneapolis: Institute for the Study of Ideologies and Literature, 1986. 1-5.

Kaminsky, Amy. Reading the Body Politic: Feminist Criticism and Latin American Women Writers. Minneapolis: U of Minnesota P, 1993.

Keve, Carolina."Las cenizas de Azucena, junto a la pirámide." Página 12 (9 December 2005): <http://www.pagina12.com.ar/diario/elpais/1-60225-2005-12-09.html>.

López, Beatriz. Hasta la victoria siempre ...Testimonio de Carmen Cornes, emigrante gallega y militante de la vida. 1992. Cordoba: Educando Ediciones, 2005.

López, Beatriz. "Inolvidable Carmiña. Libro sobre la vida de Carmen Cornes de Castiglioni." madresfundadoras.org.ar (25 October 2005): <http://www.madresfundadoras.org.ar/cultura.shtml>.

Madres de Plaza de Mayo. Cantos de vida, amor y libertad. 1981. Buenos Aires: Rafael Cedeño Editor, 1985.

Madres de Plaza de Mayo. El corazón en la escritura. Buenos Aires: Ediciones Asociación Madres de Plaza de Mayo, 1997.

Madres de Plaza de Mayo and Línea Fundadora. "Círculo de amor sobre la muerte, de Matilde Mellibovsky." madresfundadoras.org.ar (31 May 2006): <http://www.madresfundadoras.org.ar/cultura.shtml>.

Mellibovsky, Matilde. Círculo de amor sobre la muerte. 1990. Buenos Aires: Editorial Colihue, 2006.

Menchú, Rigoberta, and Elizabeth Burgos. Me llamo Rigoberta Menchú y así me nació la conciencia. México: Siglo Veintiuno Editores, 1985.

Partnoy, Alicia. El discurso de la solidaridad en los poemarios testimoniales de Argentina, Chile y Uruguay. Ann Arbor: UMI, 1997.

Sábato, Ernesto, and Un grupo de familiares. Desde el Silencio Escritos de jóvenes secuestrados - desaparecidos durante la dictadura. Buenos Aires: Sudamericana Planeta, 1985.

Taylor, Diana. "Making a Spectacle: The Mothers of the Plaza de Mayo." The Politics of Motherhood: Activist Voices from Left to Right. Ed. Alexis Jetter, Annelise Orleck, and Dianna Taylor. Hannover: UP of New England, 1997. $182-96$.

Taylor, Diana. "Performing Gender: Las Madres de la Plaza de Mayo." Negotiating Performance. Gender, Sexuality, and Theatricality in Latin/o America. Ed. Diana Taylor and Juan Villegas. Durham: Duke UP, 1994. $275-305$.

Yúdice, George. "Testimonio y concientización." Revista de Crítica Literaria Latinoamericana 36 (1992): $207-28$.

Author's profile: Alicia Partnoy teaches Spanish-language literatures and cultures at Loyola Marymount University and chairs the Department of Modern Languages and Literatures. A survivor of the Argentine secret detention camps, Partnoy is the author of The Little School: Tales of Disappearance and Survival, Revenge of the AppleVenganza de la manzana and Little Low Flying/Volando bajito, and the editor of the volume You Can't Drown the Fire: Latin American Women Writing in Exile. Partnoy is president of Proyecto VOS: Voices of Survivors, an organization that brings survivors of human rights abuses to lecture at colleges in the U.S. E-mail: <apartnoy@Imu.edu> 